\title{
NEW BLOOD PHEASANTS
}

\author{
By C. WILLIAM BEEBE,
}

\section{Curator of Birds}

The Blood Pheasants forming the genus Ithaginis fall into three groups which until recently have each been represented by a single species. Cruentus has the throat crimson and the breast streaked with the same color and with a faint green wing patch; geoffroyi has the throat and breast blue-grey and the wing patch vivid green; sinensis combines with a pale buff breast, wing-coverts of golden brown or bright rufous.

One day in northwestern Yunnan, in December, 1910, I noticed a Chinaman passing along the trail driving a number of forlorn horses with some heavy merchandise. Under the thongs which fastened one of these loads was tucked a bedraggled mass of feathers. A glint of scarlet caught my eye and I stopped the man and examined the plumage. I saw at once that it was the remains of a Blood Pheasant, and consisted of a large patch of breast feathers almost wholly scarlet and black, and two detached wings with the typically long, loose, bright green coverts of geoffroyi. I secured the plumage and learned that the man had obtained it from a native farther to the north. He could not say certainly whether all the plumage came from a single individual, and although I realized its great interest, it was impossible to put any exact interpretation upon it at the time.

While studying the specimens of pheasants in the museum of the Jardin des Plantes here in Paris I have come across two mounted specimens which clear the matter up, and show that the Blood Pheasant from the extreme northwest finger of Yunnan is a very well-marked form, by far the most beautiful and brilliantly colored 
of its genus. Lacking any data as to intermediate specimens I give it full specific rank.

\section{Ithaginis kuseri sp. nov.}

Entire forehead, chin, throat and sides of the head crimson. A narrow collar of black feathers with crimson fringes crosses the upper breast, merging at the sides with the blue-grey of the mantle. Posteriorly the breast, upper belly and corresponding sides of the body are intense crimson, marked only with very narrow shaft-lines of pale green. Behind this area the lower belly and sides down to the thigh, are brilliant clear, apple-green.

The whole head is chiefly black with no white or cream color except a trace on the nape. The upper body plumage is uniform blue-grey, with conspicuous shaft-stripes, white without any tinge of green. The wing-coverts are bright, clear green throughout, and the middle and greater coverts are very long, with recurved, decomposed barbs. Black is wholly lacking on the visible portion of these coverts, the only character being the slightly paler green shaft-stripe. The concealed bases show a rufous-brown tinge, while still more basally the feather becomes blue-grey with the narrow black lines bordering the shaft. The covert and tail fringes of crimson are well developed and the under tail coverts are brilliant crimson.

The description is of the specimen here designated as the type and is a fully adult male bird, No. 179A in the mounted collection of the Museum National D'Historie Naturelle. It is marked "Yunnan. Prince H. d'Orleans, 1896". Measurements in inches of this specimen are culmen 43 ; wing 8.5 ; tail 5.2 ; tarsus 2.5 ; middle toe and claw 2.1. There are two spurs on the right leg and a single one on the left, each about half an inch in length. The specimen is considerably moth-eaten and in a bad state of preservation.

A second specimen of Ithaginis kuseri, the only one, except my fragment, of which I know, is No. 179B in the same collection. It is a young bird in its first year, the spurs being mere flat nodules. It corresponds in all respects with the type, except that there is an even greater infusion of black throughout the plumage. The tail, which is more perfect than in the other bird, is an inch longer. Its label gives “Tsékon, Yunnan. R. P. Soulie, 1897”. This locality is in the northwestern finger of Yunnan on the Mekong River, in 
latitude $28^{\circ}$ north, and longitude about $99^{\circ}$ east, thus giving a definite location for the species.

The bird combines some of the characters of cruentus with the brilliant green wing patch of geoffroyi, but it differs in many ways from both. From Himalayan birds it at once stands apart as almost lacking the white or cream color on the anterior part of the body, in the remarkable amount of crimson, and in the geoffroyi type of wing.

I take great pleasure in naming this well-marked species in honor of Col. Anthony R. Kuser, whose interest and generosity have made possible these pheasant researches.

Heretofore we have known of no specimen of Himalayan Blood Pheasant east of extreme western Bhutan, while Ithaginis geoffroyi ranges through southeastern Tibet and touches the extreme tip of Yunnan. It has been remarked more than once that the eastern specimens of Ithaginis cruentus differed appreciably from those ranging more to the west, chiefly in the large amount of crimson streaking on the breast of the western or Nepal birds, this color being absent or very faintly indicated on birds from southern Sikhim.

After careful consideration, and for a number of reasons I think this fact worthy of permanent record and accordingly establish a sub-specific designation for the eastern and more southerly form.

\section{Ithaginis cruentus cruentus (Hardwicke)}

The male type specimen from Nepal, named Phasianus cruentus by Hardwicke in 1822, and now in the British Museum, is typically of the heavily streaked, western form. The crimson is very heavy and abundant on the breast, starting well up on the lower throat, while on the center line of the breast and laterally as well, the crimson spots are scattered over much of the ventral plumage, traces being present even on the long flank thigh feathers.

Ithaginis cruentus affinis subsp. nov.

Looking at a large series of Blood Pheasant skins from Nepal and northern Native Sikhim, the eye at once notes three distinct zones of crimson on the ventral surface, chin, mid-breast and under tail coverts. A second series of birds collected in southern Sikhim and "near Darjeeling" shows the central zone absent or nearly so. 
For example, in one such series, only six out of sixteen birds showed superficial traces of the crimson color, in the majority this hue being represented only by faint rusty stains on a few of the feathers.

In the present sub-species there is also a decided reduction in the crimson fringe on the upper tail-coverts and rectrices. A constant character separating the two forms is that in cruentus affinis the two outer pairs of tail feathers wholly lack the crimson, while in cruentus cruentus only the outer pair lacks this color, the second pair being invariably tinged and often fringed with crimson. There is no very decided differentiation in size, although the average of measurements of a large number of specimens shows the typical cruentus form to be slightly smaller than affinis.

As type of this sub-species I designate an adult male, collected in British Sikhim, Kuser-Beebe Collection, No. 387. This bird will ultimately be included in the collection presented by Col. Kuser to the American Museum in New York City.

It is important to note that many Blood Pheasants have been collected and sent to Museums with the simple locality "Darjeeling," and a number of these are more typically cruentus than affinis. This species has never existed in the vicinity of Darjeeling or even in the Darjeeling district, and the supposition is that these particular specimens were collected far north as the Singhaleela Range, which forms the divide between Nepal and Sikhim. Birds from this range with direct communication northward around the slopes of Kinchinjunga with the central Nepalese mountains we should expect to be more typical of cruentus than affinis.

In regard to the females, those from Nepal show on the whole much more crimson than birds from Sikhim. Taking the character of a distinct crimson band around the facial area and a noticeable crimson wash or tinge on the chin and throat, the proportion of its presence in typical cruentus from Nepal is about $85 \%$, as against $10 \%$ of occurrence in southern Sikhim birds and even this small percentage is based on doubtfully labelled specimens.

Even more diagnostic a character is the crimson color on the margins of the rectrices, which I have never found absent from a Nepalese female, while of southern Sikhim birds not one in ten has the faintest trace. A typical affinis female is slightly greyer in general tone than the western form, this being especially noticeable on the lesser wing feathers, where the lighter markings are 
decidedly whitish instead of warm buff. The type specimen selected is the adult female from southern Sikhim, which is No. 450 in the Kuser-Beebe Collection.

The form Ithaginis cruentusaffinis is of the same geographical class as Phasianus soemmerringii ijimae, but with more claim to recognition and record, as the latter is closely associated with $P$. s. scintillans in a broken country easily transversed by the birds in all directions, while Ithaginis cruentus affinis is found only at the southern extremity of narrow mountain ridges, separated by deep valleys which are never transversed by these lovers of high altitudes. Indeed at the present time this form may be considered. all but extinct. 


\section{$2 \mathrm{BHL}$ Biodiversity Heritage Library}

Beebe, William. 1912. "New Blood Pheasants." Zoologica : scientific contributions of the New York Zoological Society 1(10), 189-193. https://doi.org/10.5962/p.184711.

View This Item Online: $\underline{\text { https://www.biodiversitylibrary.org/item/97326 }}$ DOI: https://doi.org/10.5962/p.184711

Permalink: https://www.biodiversitylibrary.org/partpdf/184711

\section{Holding Institution}

Harvard University, Museum of Comparative Zoology, Ernst Mayr Library

\section{Sponsored by}

Harvard University, Museum of Comparative Zoology, Ernst Mayr Library

\section{Copyright \& Reuse}

Copyright Status: Public domain. The BHL considers that this work is no longer under copyright protection.

This document was created from content at the Biodiversity Heritage Library, the world's largest open access digital library for biodiversity literature and archives. Visit BHL at https://www.biodiversitylibrary.org. 